\title{
The Integration of Environmental Education in Science Materials by Using MOTORIC Learning Model
}

\author{
I Wayan Sukarjita ${ }^{1}$, Muhammad Ardi ${ }^{2}$, Abdul Rachman ${ }^{2}$, Amiruddin Supu ${ }^{1} \&$ Gufran Darma Dirawan ${ }^{2}$ \\ ${ }^{1}$ Faculty of Education, Nusa Cendana University, Indonesia \\ ${ }^{2}$ Department of Environment Education, Post Graduate Programs, Makassar State University, Indonesia \\ Correspondence: I Wayan Sukarjita, Post Graduate Programs, Makassar State University, Indonesia. E-mail: \\ wayansukarjita@yahoo.co.id
}

$\begin{array}{lc}\text { Received: September 26, } 2014 & \text { Accepted: November 3, } 2014 \quad \text { Online Published: December 30, } 2014 \\ \text { doi:10.5539/ies.v8n1p152 } & \text { URL: http://dx.doi.org/10.5539/ies.v8n1p152 }\end{array}$

\begin{abstract}
The research of the integration of Environmental Education in science subject matter by application of MOTORIC Learning models has carried out on Junior High School Kupang Nusa Tenggara Timur Indonesia. MOTORIC learning model is a Environmental Education (EE) learning model that collaborate three learning approach i.e. character approach, contextual and multimedia approaches. MOTORIC consists of seven components which constitute the acronym namely: Motivation, Observation, Talking, Orientation, Reinforcement, Implementation and Confirmation. The purpose of this research is to improve the junior high school students' knowledge about the environment. Futhermore, the study was carried out in February-May 2014, with a sample of class VII students of junior high school in Kupang Indonesia. Environmental education materials are integrated in this study include energy, living sustem, pollution, waste management and conservation. Data was measured by using multiple choice test of environmental knowledge. The data were analyzed using the Wilcoxon Signed Rank test.

The results showed at 95\% confidence level $(\alpha=0.05)$, the integration of Environmental Education materials in science subject matter of junior high school through application of MOTORIC learning models effectively improve students' knowledge of the environment by $64.15 \%$ in large groups of students meanwhile $68.07 \%$ in small group of students.
\end{abstract}

Keywords: environmental, education, MOTORIC, model, science

\section{Introduction}

Nature is a source of life for humans. Therefore, man cannot escape from the reliance by nature and the environment. To meet all the requirements (needs) and desires (wants), then humans explore natural resources excessively without being followed by remediation measures or rehabilitation of natural resources. Environmental degradation becomes result of community behavior and community attitude in managing their environment. The fact is, many phenomena of environmental change in recent years have become an event that jolted our thinking. Some unfortunate events caused by environmental degradation caused community to think backwards and connect the incident with the educational process. For example: deforestation causes erosion, floods and landslides that resulted in a lot of human casualties due to the avalanche of soil, the problem of air pollution in large cities due to the heavy use of motor vehicles, water and soil pollution, the attitude of people who still throw waste and littering the land, global warming, greenhouse effect and many others phenomena that portrait of environmental degradation. From this fact, it is needed community awareness to protect nature that has limitations and should be preserved for the continuation of existence of mankind in the future.

One effort that can be done by the government to prevent and save the environment at an early stage is to involve children from an early age in caring and loving environment. This can be done either through formal, non-formal and informal educational basis. Moreover, in formal education, efforts to recognize and cherish the environment can begin to introduce to students some of the terms associated with the environment. Environment Knowledge is needed to be implanted since early childhood with the hope that this knowledge will be the foundation for students to be even behaved positively towards the environment. Associated with this statement, Hendrawati (2009) states that childhood is a critical period as the future generation in the future. If knowledge is embedded in the way childhood is true, can be expected when he reaches adolescence and adulthood, the stock of 
knowledge, understanding and attitude formation during childhood will bring enormous positive effect that will affect their lives.

Introduction to the ecosystem, habitat and community livelihoods in the junior high and even elementary school students should gradually from planting of knowledge about the environment. By simplifying introduced the ecosystem knowledge that related to the community, the nature, the phenomena of the nature and community expectations their livelihoods in the future. Knowledge is information or intimation known or recognized by someone. Furthermore, Soekanto (2003) also explains that knowledge is the impression in the minds of men as a result of his senses and different users with confidence (beliefs), superstitions, and enlightened wrong (misinformation).

In another sense, knowledge is a variety of symptoms encountered and acquired through observation of human senses. Knowledge arises when someone uses the senses or his reason to recognize certain objects or events that have never seen or felt before. Knowledge is information that has been combined with the understanding and the potential for further action, which is then attached to one's mind. In addition, Notoatmodjo (2007) also explains that knowledge can be interpreted as the result of human sensing of objects through the senses of its senses of sight, hearing, smell, taste and touch at a time which in itself will generate a sensing knowledge. Much of the knowledge gained from sensing the eyes and ears. It is greatly influenced by one's knowledge and perception of the intensity of the attention object which is a guide in shaping attitudes even one's actions.

In general, knowledge of the predictive ability of something as a result of recognition of a particular form of pattern s. Knowledge arises when someone uses the senses or cultural sense to explore an object, event or form specific patterns that have never seen or felt before. Person's ability to use his senses to recognize an object or a specific incident different from each other, depending on the sensitivity and intensity of sensory stimuli received one. Therefore, it has a level of knowledge and level of intensity as part of a process of thought if someone on the observed object or event. Accordingly, Bloom and Kratwohl (1956) as quoted by Rusman (2012) classifies knowledge as cognitive domains (cognitive) in six aspects or levels of thinking processes, ranging from the lowest level to the highest level. The sixth level or aspect in question is (1) knowledge (C1); (2) comprehension (C2); (3) Applications (C3); (4) Analysis (C4); (5) Synthesis (C5) and (6) evaluation (C6).

The sixth level of knowledge of the above, then by Anderson (2001) revised by changing the form of the noun into a verb, as well as a change in the level of the fifth and sixth. According to Anderson (2001) as cited in Rohmad (2012) that the cognitive domains has six aspects or levels of thinking processes ranging from the Remembering (C1), Understanding (C2), Applying (C3), Analyzing (C4), Evaluating (C5) to the level of the highest thought process that is Creating (C6).

The Research in an effort to raise awareness of environmental preservation for junior high school students had conducted by Puspandari (2008) by applying Contextual Teaching and Learning (CTL) in the learning of Population and Environment Education by sample is Junior High Schools students in Balikpapan, South Kalimantan. The results of research show that, (1) In Population and Environment Education learning, students need to gain direct experience or at least see the real case about environmental, (2) students began to realize the importance of environmental sustainability, (3) application of learning model CTL in Population and Environment Education learning able to optimize the appearance of intellectual potential, creativity, emotional intelligence and student adversity (Puspandari, 2008).

In formal education in junior high school, knowledge about the environment can be provided to students, among others, through the Environmental Education (EE) lessons. Environmental Education (EE) is the activity in the field of environmental education organized by schools, consisting of elementary education, secondary education and higher education and is done in a structured and tiered. According Arianto (1988) that the Environmental Education (EE) teaching through formal education can be achieved through two approaches, namely:

(1) monolithic approach, the Environmental Education (EE) as a stand-alone subject in line with other subjects, (2) an integrative approach, which combines or unites Environmental Education (EE) material into a particular subject, for example in science lessons. However, when it sis referring to the concept of ESD (Education for Sustainable Development) then Environmental Education in formal learning for primary and secondary education done in integrative approach (Deputy for Environmental Communication and Community Empowerment, Ministry of Environment, 2012). Associated with it, then if Environmental Education is not listed in the curriculum for Environmental Education can be taught in an integrated manner on other subjects.

Science is one of the subjects taught in the secondary school. Science is the nature and meaning of various phenomena/behaviors/characteristics that are packed into a set of theories or concepts through the scientific process by humans. Theory or concept is organized into an inspiration for the creation of technology that is utilized 
for human life (Mariana, 2009). Science in the Junior High Schools include; material of physics, chemistry and biology.

When a teacher wishes to integrate the Environmental Education materials into science materials, will arise a question, "how to integrate EE into science learning effectively and practicaly?" Effective and practical implies that the model is applicable not interfere with subject matter that is science, but easily insert environmental education materials into the learning process. On this occasion, the authors introduce a learning model that can be used in learning are integrated EE in science learning. This model is named MOTORIC which stands for Motivation, Observation, Talking, Orientation, Reinforcement, Implementation and Confirmation that shows seven components of learning process in this model. The learning model is based on the third approach is the approach of learning EE character, contextual and multimedia refers to the theories of behaviorism, in which learning is a change in behavior as a result of the interaction between stimulus and response. According to this theory, the most important is the input in the form of stimulus and the output in the form of response.

The MOTORIC Learning is essentially a study designed to combine several strategies and learning approach that is now being referred to as a learning approach that prioritizes active students to think, be factual, bold expression, and is able to implement the knowledge obtained by students in the learning process in the form of positive attitude in social life. MOTORIC stand for several aksioma i.e. Motivation, Observation, Talking, Orientation, Reinforcement, Implementation and Reflection depicting the seven components of learning that characterizes MOTORIC learning. MOTORIC learning model is applied in the learning environment is based on three learning approach, which is environmentally approach to the character, contextual learning and multimedia learning as the application of technology in learning. The three approaches, which approaches the character, and the contextual approach to learning multimedia forms of learning approaches appropriate and in line with the five learning component in the curriculum in 2013, are watching, asking, gather information, associating and communicating.

Character is a learning approach that is more about the attitude that characterizes each individual student. As Rohman (2012) explains that the character is a way of thinking, attitude and behavior that is characteristic of each individual to live and work together, both within the family, community, nation and state. The character of individual is an individual who can make decisions and be ready to account for every effect and the decision he made. Character education is a plus character education, ie education that involves aspects of cognitive, feeling and action. Without these three aspects, it will not be effective character education.

Contextual approach is a concept which helps teachers link between the learning materials taught students with real-world situations and encourage students to make connections between the knowledge possessed by its application in their lives as family members, citizens and workers (Komalasari, 2011). Meanwhile, the concept of a multimedia approach that underlies the MOTORIC model this is learning environment that seek to present factual issues concerning environmental audio-visual equipment. One goal is for the student brought in a sense of real-world environmental problems associated with that display. Environmental Education learning cannot be separated from the role of the media, especially the four media, visual media, audio-visual media, media people and media settings. Impressions through photographs and audio-visual recordings of how sengasaranya people who lived in the stricken region where floods, landslides, droughts and crop failure due to water sultry as the impact of a green area that serves as a water catchment has been broken and the like events, is expected to arouse feelings (feeling) students to help preserve the environment. Media especially multimedia, according to research Hussein (2010) can motivate students to behave and act.

Chosen character, contextual and multimedia approach as learning concepts underlying MOTORIC models of learning, because according to the curriculum 2013 expectations as set out by the Minister of Education and Culture of the Republic of Indonesia Number 65 Year 2013 About Standard of Process Primary and Secondary Education, that the learning objectives in the New curriculum 2013 include the development of the realm of attitudes, knowledge and skills elaborated in every educational unit of learning. In addition, the third domain has a trajectory acquisition of competence or different psychological processes. The attitude is gained through the activities of learners "receive, run, respect, appreciate, and practice". Knowledge gained through the activity of "remembering, understanding, applying, analyzing, evaluating, development. Meanwhile learners acquired skills through activity "observe, ask, try, reason, describe, and create". The third characteristic differences and their sphere of competence acquisition trajectory participate affect the characteristics of the standard process. To strengthen the scientific approach, thematic integrated (inter thematic subjects), and thematic (in the subject) it needs to be designed and implemented an innovative learning to encourage the achievement of a balance of competence attitudes, knowledge and skills. The MOTORIC learning model is one alternative learning innovation to achieve the intended purpose. Therefore, to achieve a balance of student attitudes and knowledge 
about the environment in learning environment, then this MOTORIC learning concept which refers to input a positive character to the environment-science subject through contextual learning by using multimedia learning.

The MOTORIC learning model has seven components learning, namely:

(1) Motivation, the teachers motivate their students in the learning process activity apperception appropriate subject matter in the classroom environment will be discussed. At this stage the teacher motivates through questions or statements that provoke interest students to feel interested in following the topic material that will be submitted by teachers. Phase motivation is actually very close to the next stage of the observation stage.

(2) Observation, the students make observations directly or indirectly related to environmental topics to be discussed. Direct observation is the observation by directly observe to the environmental topics that will discussed (outside the classroom). While the indirect observation is the observation can been done through the use of multimedia that has been prepared in advance by the teacher.

(3) Talking, the students form groups and discuss appropriate discussion guide has been prepared teachers. Teachers act as facilitators for each group discussion. The result of the discussion then briefly presented by each group.

(4) Orientation, the teacher directed that the conclusion of the discussion groups according to subject matter that is being discussed. In the orientation phase, the teacher's role a bit more dominant than the students, the goal that the conclusions made in strict accordance with the concept of the material covered during the learning takes place.

(5) Reinforcement, Reinforcement is done primarily to provide teachers with the knowledge and the related strengthening of environmental attitudes of students.

(6) Implementation, the students implement what they have learned at the meeting in attitude in daily life and in social life. This implementation is more geared to fostering positive attitudes of students in maintaining and preserving the surrounding environment. At this stage, students implement the material in the life of the surrounding environment through Attitude Implementation Guide (AIG) of environmental prepared by the teachers. Implementation of a positive attitude towards the environment can be done starting from a small scope like cleanliness class, school yard to residence students.

(7) Confirmation, at the end of the activity, the teacher always reminds students to always be positive towards environmental conservation efforts.

\section{Research and Methods}

The research of implementation MOTORIC model was conducted in April-May 2014 at a class VII student of Junior High School 13 Kupang Indonesia. The test is done twice, i.e in small groups totaling 12 students and large groups totaling 21 students. Before the trial experiment, the researcher conducted pre-test to determine students' prior knowledge about the environment. The implementation of MOTORIC model on a small group of samples is done by inserting environmental messages on key words science lessons that can be attributed to the environment. The effectiveness and practicality of the model is indicated by an increase in students' knowledge about the environment. The steps of Research and Development models approach is used pre-test before treatment is done, and at the end of the implementation of the model is done post-test about environmental knowledge with 35 question items.

The Integration of environmental education materials into science lessons cover three topics, there are: energy, living system pollution, waste and conservation. Those materials are integrated environment in materials science with the topic of energy and system life. Analysis of data from the pre-post test knowledge environment for the sample group used Wilcoxon Signed Rank test (Sudjana, 2005).

\section{Results and Discussion}

Trials of integration environmental education in the science material by using MOTORIC learning model on Junior High School had done through two-stage models. The implementation of MOTORIC model on a small group of samples is done by inserting environmental messages on key words science lessons that can be attributed to the environment. To facilitate delivering of learning material used science books that have been inserted with environmental messages and picture messages of interest in accordance with the character of junior high school students. In addition, also be used to guide the implementation of the attitude inspires students to love the attitude of the environment. In order for the messages to be conveyed environment more attractive, multimedia is used along with the video. The seven existing learning syntax in the MOTORIC model taught as one-on-one integrated whole as a model of science learning but inserted with environmental messages. The 
model innovation is to emphasize to students that they basically are learning the material instead of learning about science and the environment. However, with the inclusion of environmental messages through the characters approach, contextual and multimedia use their unwitting students have also been learning environment.

Trials on small groups and large groups performed 5 times face to face on schedule by applies curriculum 2013 in the sample schools. Science material is tested with the topic of energy and life systems with integrated environmental materials include pollution, litter and conservation. At the end of the experiment trial, the researcher was conducted post-test, to determine how much the MOTORIC model effectiveness in improving students' knowledge of the environment. Based on the results of pre-post test in a small group and the group, the data obtained as Table 1 below.

Table 1. Pre-post test results for small and large groups' data

\begin{tabular}{lllll}
\hline & \multicolumn{2}{l}{ Small groups } & \multicolumn{2}{l}{ Large groups } \\
\cline { 2 - 6 } & Pre & Post & Pre & Post \\
\hline Number of samples & 12 & 12 & 21 & 21 \\
Means & 13.8 & 23.3 & 17.0 & 27.9 \\
Minimum Value & 8 & 18 & 12 & 20 \\
Maximum Value & 20 & 30 & 23 & 33 \\
standard deviation & 2.98 & 3.70 & 2.74 & 3.67 \\
Percentage of Improvement (\%) & 68.07 & & 64.15 & \\
\hline
\end{tabular}

Based on the data, as shown in Table 1 above, it appears that the integration of material Environmental Education in the subject matter of science through the MOTORIC learning model effective increase students' knowledge about the environment. In a small pilot group, an increase in students' knowledge of the environment before and after the application of the MOTORIC model is equal to $68.07 \%$, while trials on large groups of $64.15 \%$. This suggests that environmental messages are integrated in science lessons were able to increase the students' knowledge of environmental issues, especially related to waste, pollution issues and environmental conservation issues. Increasing students 'knowledge of the environment is expected to be a good influence on students' attitudes toward the environment.

The integration of environmental materials by MOTORIC models in science are contextual material that is part of the MOTORIC model, assist students in understanding the importance of the environment for students. Similarly, the role of instructional videos that are included in the MOTORIC model can developed sense of love and sympathy for the students on the environment. Therefore, the approach to the concept of the use of media characters (what is seen) would make it easier for students in recording a variety of knowledge about environmental issues. Increasing students' knowledge of the environment by $68.07 \%$ in the test sample and the small group of $64.15 \%$ on a large test sample group indicated that the integration of environmental education materials through MOTORIC models in materials science of junior high schools effectively increase students' knowledge about the environment.

The percentage of increase in the mean pre-post students' knowledge of the environment after application of MOTORIC learning models significantly as shown by Figure 1. 


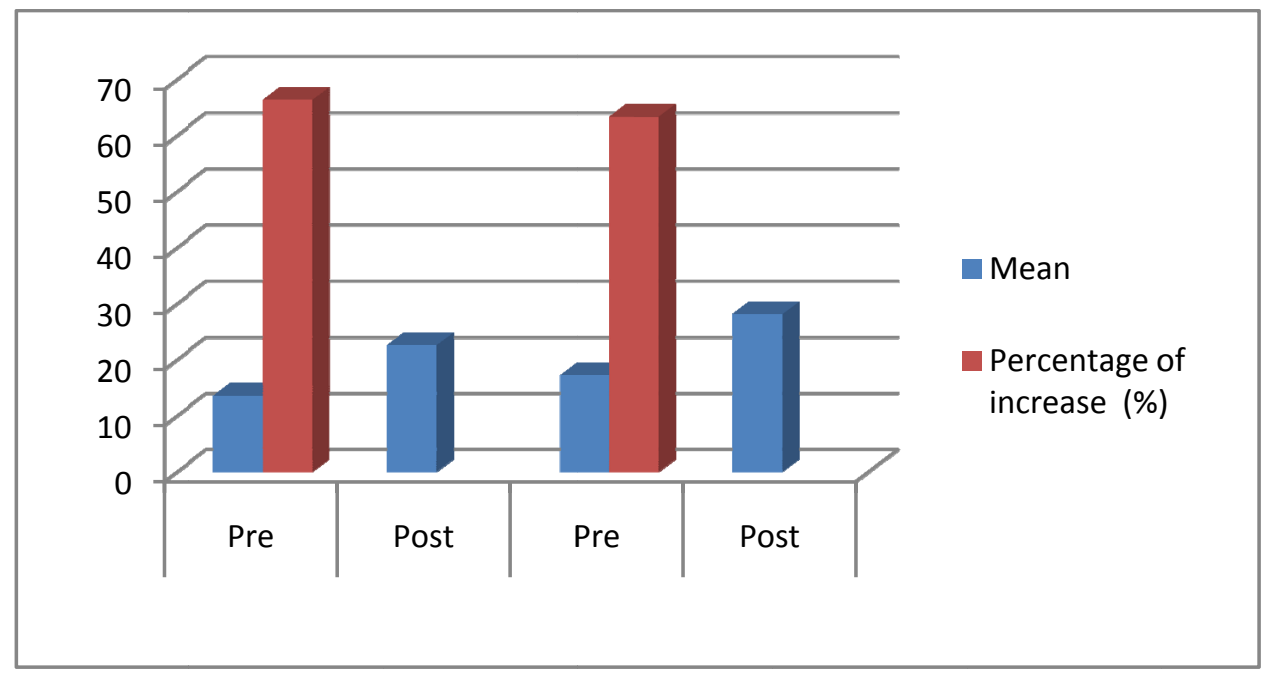

Figure 1. Charts of knowledge enhancement percentage for students in small and large groups

To see the significance of the difference between the pre-test to post-test knowledge of the value of environmental by groups Wilcoxon Signed Rank test. Based on the analysis of data obtained significant differences in the value of pre-test to post-test students' knowledge of the environment as the obtained results were treated as shown in Table 2 and Table 3.

Tabel 2. The Wilcoxon signed ranks test for the small group

\begin{tabular}{llll}
\hline & $\mathrm{N}$ & Mean Rank & Sum of Rank \\
\hline Post-Pre Negative Ranks & $0 \mathrm{a}$ & .00 & .00 \\
Positive Ranks & $12 \mathrm{~b}$ & 6.50 & 78.00 \\
Ties & $0 \mathrm{c}$ & & \\
Total & 12 & & \\
\hline
\end{tabular}
a. Post $<$ Pre
b. Post $>$ Pre
C, Post $=$ Pre

\begin{tabular}{ll}
\hline Test Statistics $^{\mathrm{b}}$ & Post-Pre \\
& $-3.068^{\mathrm{a}}$ \\
$\mathrm{z}$ & .002 \\
Asymp. Sig. (2-tailed) & \\
& \\
a. Based on negative ranks \\
b. Wilcoxon Signed Rank Test \\
\hline
\end{tabular}

Based on the analysis results of the Wilcoxon Signed Rank test, the value of $Z=-3.068$, with $n=12$, the value of $\mu_{w}$ is 39 and $\sigma_{w}$ is 12.74. Based on these values obtained $w_{o b s}$ is 7.72. Meanwhile, for $n=12$ at level $\alpha=0.05$ the value of $\mathrm{w}_{\text {crtitical }}$ is 14 . Because the value of $\mathrm{w}_{\text {obs }}<\mathrm{w}_{\text {critical }}$ it can be concluded that there are significant differences between the students' knowledge of the environment before and after the application the application of the MOTORIC learning model. Something similar happened with a large group of test samples as indicated in Table 3. 
Tabel 3. The Wilcoxon signed ranks test for the large group

\begin{tabular}{llll}
\hline & $\mathrm{N}$ & Mean Rank & Sum of Rank \\
\hline Post-Pre Negative Ranks & $0^{\mathrm{a}}$ & .00 & .00 \\
$\quad{ }^{\text {Positive Ranks }}$ & $21^{\mathrm{b}}$ & 11.00 & 231.00 \\
$\quad 0^{\mathrm{c}}$ & & \\
$\quad$ Ties & 21 & & \\
\hline d. Post $<$ Pre & & & \\
e. Post $>$ Pre & & \\
f. Post $=$ Pre & & \\
\hline Test Statistics & & \\
z & Post - Pre & \\
Asymp. Sig. (2-tailed) & $-4.020^{\mathrm{a}}$ & \\
c. Based on negative ranks & .000 & \\
d. Wilcoxon Signed Rank Test & & \\
\hline
\end{tabular}

For the large group, we find $\mathrm{z}=-4.020$. For $\mathrm{n}=21$, the value of $\mu_{\mathrm{w}}$ is 115 and $\sigma_{\mathrm{w}}$ is 21.75 . Based on these values obtained $\mathrm{w}_{\mathrm{obs}}=27.56$. Meanwhile, for $\mathrm{n}=21$ at level $\alpha=0.05$ the value of $\mathrm{w}_{\text {crtitical }}$ is 59 . Because the value of $\mathrm{w}_{\text {obs }}<\mathrm{w}_{\text {critical }}$ it can be concluded that there are significant differences between the students' knowledge of the environment before and after the application MOTORIC learning model. Based on two groups of samples analysis results indicate that the integration of environmental education materials that exist in phases MOTORIC models can be effective to improve students' knowledge of the environment at the $95 \%$ confidence level ( $\alpha=0.05$ level).

The increasing students' knowledge of the environment is expected to have an impact on increasing students' positive attitudes towards the environment. As the result of research conducted by Masmuddin (2011) with a sample of Junior High Schools at Pamboang District of Pamboang, Majene West Sulawesi shows that there is a positive relationship between students' environmental knowledge with attitude against environmental hygiene. Therefore, the integration of environmental education materials on junior high school science lessons through the MOTORIC learning model practicaly and effectively applied to embed and enhance the student's knowledge about environment.

\section{Conclusion}

Based on the analysis and discussion as described above, it can be concluded as follows:

Integration of environmental education materials can be done through the application of MOTORIC learning models.

Integration of environmental education materials on junior high school science lessons through the application of MOTORIC learning models in the sample small group test of students were able to increase the knowledge about the environment amounted to $68.07 \%$, while the large group of test samples was $64.15 \%$.

Accordingly, it can be said that the integration of environmental education materials on junior high school science lessons through the application of MOTORIC learning models can increasing the students' knowledge about the environment.

\section{Acknowledgements}

Thank you submitted to: (1) Prof. Dr. Gufran D. Dirawan, M.EMD as Chairman of Departemen of Environment Education, Post Graduate Programs, Makassar State University, Indonesia who have given permission to conduct research, (2) Prof. Muhammad Ardi as a promoter, (3) Dr. Abdul Rahman as Co Promoter 1 and (4) Dr. Amirudiin Supu, S.Pd., M.Si as Co Promoter 2 which has guided the development of proposals for research to take place. Thanks are also submitted to the Graduate Program of Makassar State University who has provided administrative facilities during the research process. 


\section{References}

Arianto, I. (1988). Population and Environmental Education at the Teachers' Training College. Jakarta: Department of Education, Directorate of Higher Education, the Directorate General of Primary and Secondary Education.

Deputy for Environmental Communication and Community Empowerment. (2012). Guideline Development Outline the Content Material of Environmental Education. Jakarta: Ministry of Environment.

Hendrawati, S. (2009). Environmental Education and Its Application in Education for Elementary School Students. Research papers: Environmental Education. Retrieved from http://erma.student.umm.ac.id/download-aspdf/umm_article_10.pdf, accessed January 24, 2013

Hussein, G. (2010). The Attitudes of Undergraduate Students towards Motivation and Technology in a Foreign Language Classroom. International Journal of Learning and Teaching, 2(2), 14-24. Retrieved from http://www.world-education-center.org/index.php/ijlt/article/viewFile/354/pdf_62

Komalasari, K. (2011). Contextual Learning, Concepts and Applications. Bandung: PT. Refika Aditama.

Mariana Alit and Praginda Wandy. (2009). Natural Science Education. Bandung: Centre for Development and Empowerment of Teachers and Education Personnel Natural Sciences.

Masmuddin, K. (2011). Relationship between Students' Environmental Knowledge with Students' Attitudes toward School Environmental Hygiene Junior High School N 4 Pamboang Majene, West Sulawesi province (Thesis, Not Published, State University of Makassar).

Notoatmodjo, S. (2007). Promotion of Health and Behavioral Sciences. Jakarta: Rineka Cipta.

Puspandari. (2008). Efforts to Raise Awareness through Environmental Conservation trough Population and Environment Education Learning-Based Contextual Teaching and Learning. Journal of Innovative Education, 4(1), 28-30.

Rohmad. (2012). Revised Bloom's Taxonomy. Retrieved November 16, 2013 from http://www4.uwsp.edu/education/lwilson/curric/ newtaxonomy.htm

Rohman, M. (2012). Curriculum Character. Jakarta: Prestasi Pustaka.

Rusman. (2012). Learning Models. Jakarta: Raja Grafindo Persada.

Soekanto, S. (2003). Sociology an Introduction. Jakarta: PT. Raja Grafindo Persada.

Sudjana. (2005). Statistical Methods. Bandung: Tarsito.

\section{Copyrights}

Copyright for this article is retained by the author(s), with first publication rights granted to the journal.

This is an open-access article distributed under the terms and conditions of the Creative Commons Attribution license (http://creativecommons.org/licenses/by/3.0/). 